\title{
Antimicrobial Potential of Rhizospheric Bacteria Streptobacillus sp.
}

\author{
Jay Kishor Prasad ${ }^{1}\left(\mathbb{D}\right.$, Riddha Dey $^{1}(\mathbb{D})$ and Richa Raghuwanshi* ${ }^{2}$ \\ ${ }^{1}$ Department of Botany, Institute of Science, Banaras Hindu University, Varanasi - 221 005, Uttar Pradesh, India. \\ ${ }^{2}$ Department of Botany, Mahila Mahavidyalaya, Banaras Hindu University, Varanasi - 221 005, Uttar Pradesh, \\ India.
}

\begin{abstract}
Rhizospheric bacteria exhibiting antagonistic effects are a good source for the production of antibiotics. The antibiotics produced are naturally bactericidal or bacteriostatic in nature. In the present investigation thirty-five rhizospheric bacteria were isolated from different soil samples. Agar well diffusion method, streak agar method, disc diffusion method and biochemical tests were performed to screen the ten antibiotic-producing bacteria. Among them, strain JRR34 selected on the basis of primary antagonistic activity was identified as Streptobacillus sp. Media optimisation was done to ensure maximum production of secondary metabolites. Streptobacillus sp. JRR34 showed good inhibitory activity against Escherichia coli, Pseudomonas aeruginosa and Staphylococcus aureus. The ethyl crude extract of Streptobacillus Sp. JRR34 rhizobacteria possessing good antagonistic activity against a wide range of pathogenic bacteria can be a vital source of novel antibiotics.
\end{abstract}

Keywords: Antibiosis, crude extract, pathogens, rhizospheric bacteria, secondary metabolites, Streptobacillus

*Correspondence: richabhu@yahoo.co.in

(Received: August 13, 2021; accepted: September 09, 2021)

Citation: Prasad JK, Dey R, Raghuwanshi R. Antimicrobial Potential of Rhizospheric Bacteria Streptobacillus sp.. J Pure Appl Microbiol. 2021;15(4):1846-1854. doi: 10.22207/JPAM.15.4.01

C The Author(s) 2021. Open Access. This article is distributed under the terms of the Creative Commons Attribution 4.0 International License which permits unrestricted use, sharing, distribution, and reproduction in any medium, provided you give appropriate credit to the original author(s) and the source, provide a link to the Creative Commons license, and indicate if changes were made. 


\section{INTRODUCTION}

Bacterial isolates produce organic compounds known as antibiotics, which are toxic towards pathogens and helps the bacterial community to overcome the biotic stress by suppressing the growth of the invading microorganisms. ${ }^{1}$ Flocculated microorganisms exhibit high resistance to biocidal compounds. ${ }^{2}$ The microorganisms producing antibiotics shows more longevity as compared to the non-producers. The on-going global research for last four decades has increased the commercial production of antibiotics upto two million tons per annum. ${ }^{3}$ Recently it was observed that antibiotics show varied effects on other microorganisms in terms of virulence, modification in transcription, biofilm formation and motility. ${ }^{4}$ The production of antibiotics occurs maximally during stationary phase and is influenced by several factors like nutrient supply, oxygenation, temperature and $\mathrm{pH} .{ }^{5}$ Singh et al. ${ }^{6}$ reported that Brevibacillus laterosporus GI-9 produces bacteriocin which has proteolysis and bactericidal activity. Burkholderia seminalis secretes bioactive compound pyrrolo(1,2-a) pyrazine-1,4-dione, hexahydro (PPDH) and pyrrolo(1,2-a)pyrazine-1,4-dione, hexahydro-3(2methylpropyl) (PPDHMP) which exhibit growthsuppressing activities towards multidrug resistant Staphylococcus aureus. ${ }^{7}$ The present study was therefore aimed to observe the antibiosis abilities of the rhizospheric bacterial isolates against pathogenic bacteria viz. Escherichia coli (E. coli), Pseudomonas aeruginosa (P. aeruginosa) and Staphylococcus aureus (S. aureus) through antagonistic activity.

\section{MATERIALS AND METHODS \\ Sample collection}

Rhizospheric soil samples were randomly collected during winter season from different locations of agricultural research farm (ARF), Institute of Agricultural Sciences and Rajiv Gandhi South Campus (RGSC) of Banaras Hindu University $\left(25.3176^{\circ} \mathrm{N}, 82.9739^{\circ} \mathrm{E}\right)$, Varanasi, India having a tropical climate. The soil samples were collected in isothermic polybags and stored in refrigerator at $4^{\circ} \mathrm{C}$.

Isolation \& characterization of bacterial isolates

Each soil samples weighing $0.5 \mathrm{~g}$ were suspended in $5 \mathrm{ml}$ of sterile distilled water amended with sodium chloride $(8.5 \mathrm{~g} / \mathrm{L})$ followed by shaking using vortex mixer. Further 5 -fold serial dilution was done. $20 \mu \mathrm{l}$ of each dilution $\left(10^{-3}, 10^{-4}, 10^{-5}\right)$ was spread evenly on nutrient agar medium $(\mathrm{pH} 7.2)$ through spread plating technique and further incubated at $37^{\circ} \mathrm{C}$ for 48 hours. A total of 35 bacterial colonies developed on NA plate of which ten bacterial colonies showing discrete morphology were picked up and each of them were re-streaked to get a pure culture plate. ${ }^{8,9}$ Morphological study of the 10 bacterial isolates was done for the characters viz. colour, dryness, roughness, colony shape, colony size, gram staining and endospore staining. Parameters selected for biochemical characterization of the selected isolates were catalase production, mannitol fermentation and methyl red test. ${ }^{11}$

\section{Primary screening for Antibiosis}

Antibiosis test is helpful in identifying microbes producing diffusible low molecular weight compounds possessing antifungal/ antibacterial activity. The ten bacterial isolates were therefore screened on the basis of their inhibitory activity against the pathogenic bacteria (E. coli, P. aeruginosa and S. aureus). For primary antibiosis test, broth cultures of the isolated bacteria were used to check its inhibitory activity against the selected pathogens by agar well diffusion method. 20ul inoculum of each pathogen was spread on solidified nutrient agar media plates. Sterilized $1000 \mu$ l micro tip (diameter $8 \mathrm{~cm}$ ) were used for making the wells on the agar plate. $50 \mu \mathrm{l}$ of the bacterial broths were pipetted in the wells and incubated at $37^{\circ} \mathrm{C}$ for $24 \mathrm{~h} .{ }^{10}$ Bacterial strain JRR34 manifesting significant inhibitory activity during primary screening was optimized for growth conditions and subjected to secondary screening.

\section{Optimization of growth conditions}

Growth conditions were optimized for the strain JRR34 to get maximum secondary metabolite production. The liquid fermentation nutrient broth containing carbon sources (conc. $1 \%)$ : glucose, sucrose, lactose and mannitol; nitrogen sources (conc. 1.3\%): yeast extract, beef extract, peptone and ammonium chloride; metal ions (conc. $0.1 \%$ ): ferrous sulphate, lead nitrate and copper sulphate was used in the present study. Furthermore, $\mathrm{pH}$ range: $5,7,9,11$ and temperature: $4{ }^{\circ} \mathrm{C}, 25^{\circ} \mathrm{C}, 37^{\circ} \mathrm{C}, 50^{\circ} \mathrm{C}$ were also 


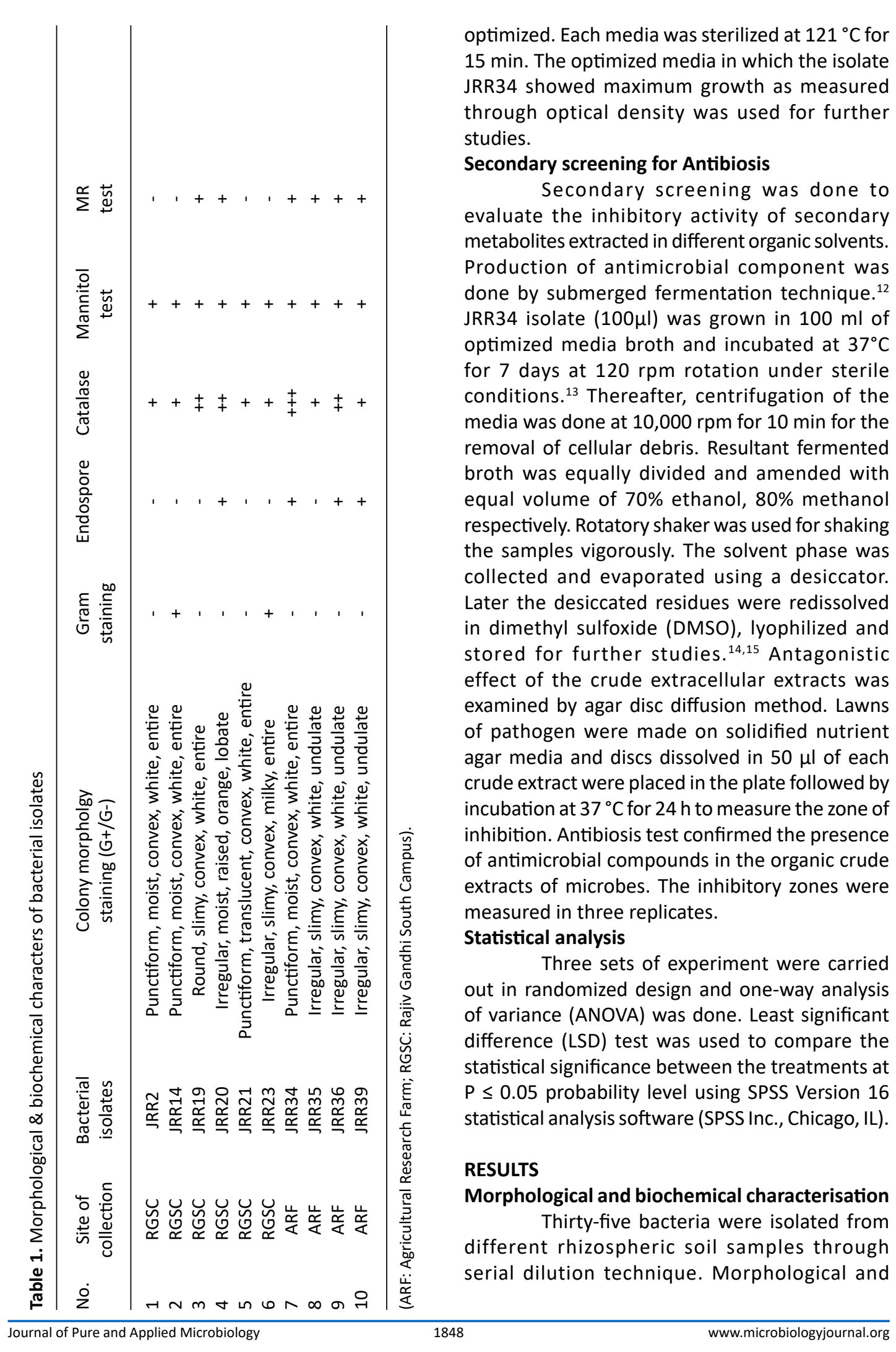


biochemical characteristics of the isolates showing discrete colony are listed in Table 1.

The selected isolate JRR34 was identified as Streptobacillus sp. on the basis of morphological and biochemical studies as described in Bergey's Manual of Determinative Bacteriology ${ }^{16}$ and Manual for the identification of Medical Bacteria. ${ }^{17}$ JRR34 was gram negative, rod-shaped bacteria, growing in long chains and showing slightly acidic growth condition and optimum growth temperature $37^{\circ} \mathrm{C}$.

\section{Test for Antibiosis}

Bacterial strains isolated from rhizospheric soil showed significant antibiosis activity as measured through the inhibition zone (Fig. 1 a \& b). The pathogens used were $E$. coli, P. aeruginosa and $S$. aureus. The bacterial strain JRR34 showed maximum antimicrobial activity during the primary screening against the pathogens. The well diffusion plates are shown in Fig. 1 (a).

\section{Optimization of growth conditions}

Optimization of culture conditions was done to provide ideal conditions for growth to the isolate JRR34 and for better production of secondary metabolite under in vitro conditions. The growth of JRR34 was optimized in 100 $\mathrm{ml}$ nutrient broth media and the growth was measured in terms of optical density. Maximum growth of JRR34 was observed on day 5 (1.18) and day 6 (1.24). Day 7 (1.22) onwards a decrease in optical density depicting death phase initiation was observed. Fig. 2 depicts the growth of the selected isolate graphically representing exponential and stationary phase of the isolate. Also, maximum growth (0.48) was observed in $\mathrm{pH} 5$ whereas minimum growth (0.06) was observed at
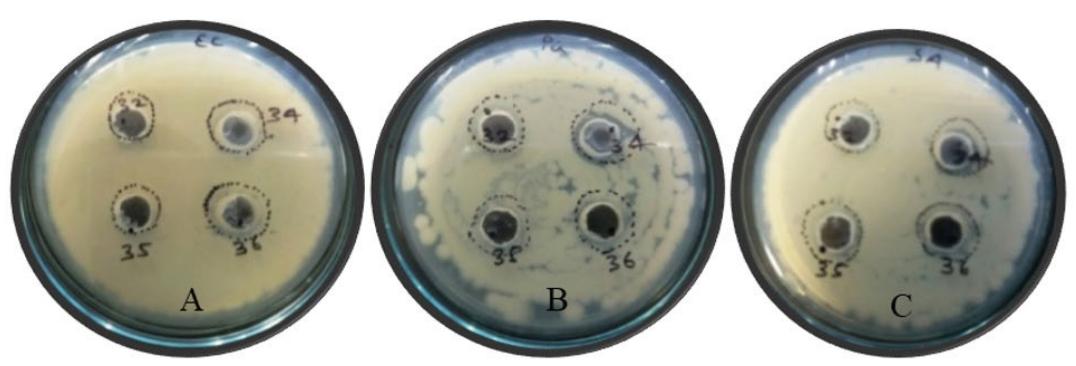

Fig. 1(a). Screening bacterial isolates for antibiosis activity by well diffusion method against (A) E. coli (B) P. aeruginosa (C) S. aureus.

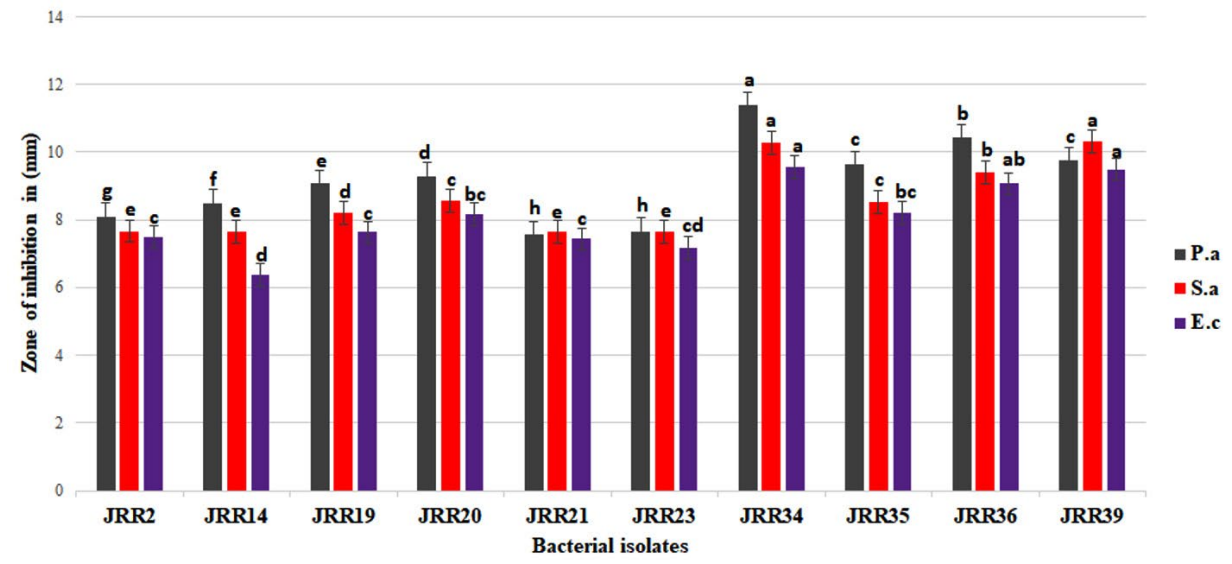

Fig. 1(b). Primary screening of bacterial isolates for antibiosis activity by well diffusion method against pathogenic bacteria $P$. aeruginosa, $S$. aureus and E. coli.

(Results are expressed as means of three replicates and vertical bars indicate standard deviations of the means. Different letters indicate significant differences among bacterial isolate activity taken for the same bacterium according to Duncan's multiple range test at $\mathrm{P} \leq 0.05$ ) 
$\mathrm{pH}$ 11. Fig. 3 represents the effect of $\mathrm{pH}$ on growth of JRR34. Further it was observed that growth of JRR34 was best at $37^{\circ} \mathrm{C}$ when compared for the temperature conditions. The streak plates showing the growth of JRR34 under various temperature conditions is shown in Fig. 4 .

Maximum growth of the selected isolate JRR34 was observed to be in the optimized media containing Yeast extract $(1.25 \%), \mathrm{FeSO}_{4}(0.1 \mathrm{~g} / \mathrm{l})$, $\mathrm{K}_{2} \mathrm{HPO}_{4}(0.5 \mathrm{~g} / \mathrm{l})$, Lactose $(1.0 \%), \mathrm{NaCl}(0.2 \mathrm{~g})$ having $\mathrm{pH} 5$ with incubation temperature of $37^{\circ} \mathrm{C}$ for 5 days.

\section{Secondary screening}

Assessment was done for the antimicrobial properties of Streptobacillus sp. extracellular components purified by solvent extraction method. Ethyl extract showed higher inhibition of the pathogens as compared to methyl extract. Tetracycline and DMSO were used as positive and negative controls respectively. Plates with zone of inhibition are shown in Fig. 5 .

A comparative analysis showed that Streptobacillus sp. had a significant difference in antimicrobial activity (Fig. 6 ) in different solvents. Although it exhibited inhibiting activity in both methyl and ethyl extracts the activity was higher in ethyl extract. It conferred $2 \%$ increase in zone of inhibition against $E$. coli, $4 \%$ increase against $P$. aeruginosa and $13 \%$ increase against S. aureus in ethyl extract as compared to methyl extract.

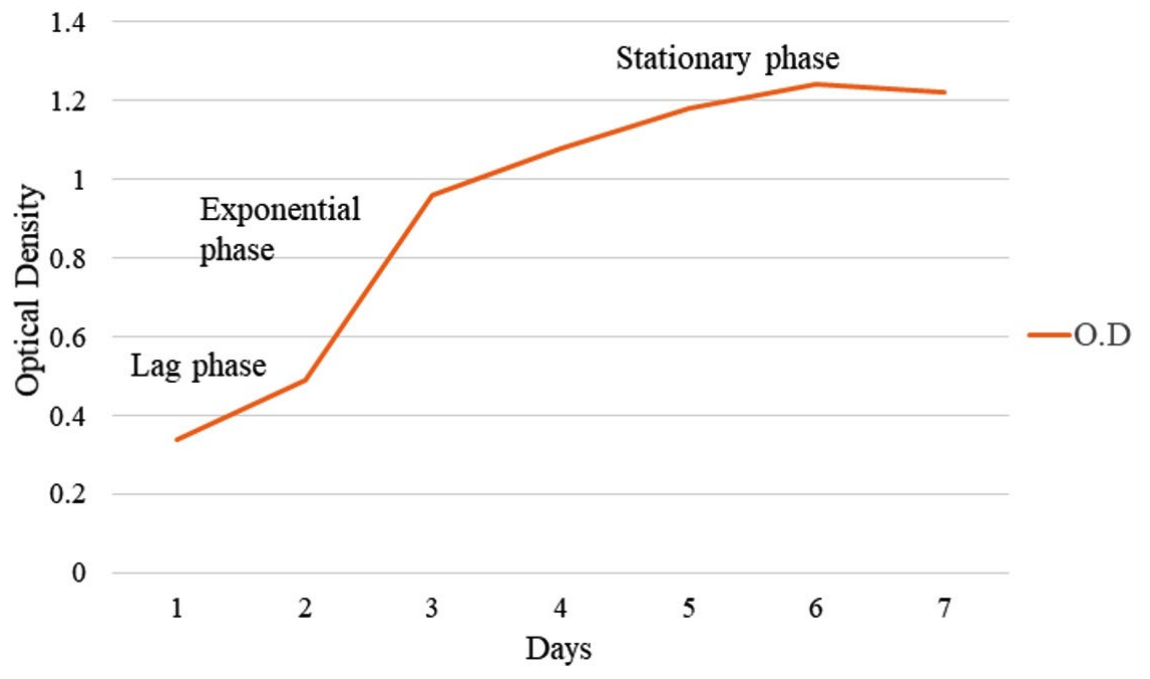

Fig. 2. Growth curve of JRR34

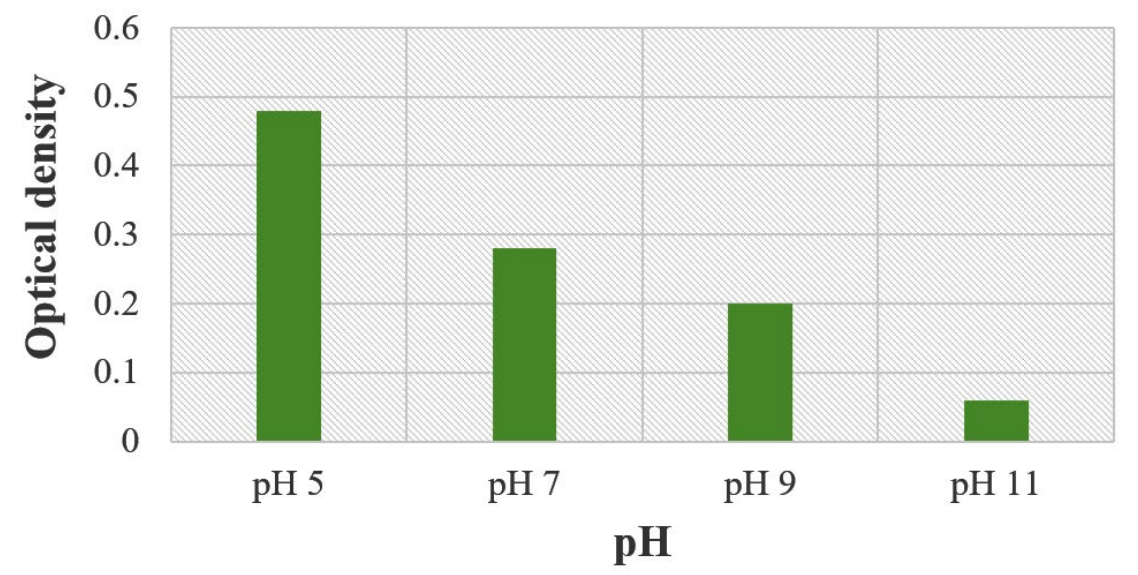

Fig.3. Effect of $\mathrm{pH}$ on growth of JRR34 
Streptobacillus sp. exhibited more inhibitory action against S. aureus ( $22.2 \mathrm{~mm}$ ) as compared to E. coli $(18.2 \mathrm{~mm})$ and $P$. aeruginosa $(19.5 \mathrm{~mm})$ in ethyl extract. Tetracycline taken as positive control showed maximum inhibition zone of $21.5 \mathrm{~mm}$, $24.6 \mathrm{~mm}, 23.8 \mathrm{~mm}$ against $E$. coli, P. aeruginosa and S. aureus respectively.

\section{DISCUSSION}

Thirty-five bacterial isolates were obtained from rhizospheric soil of which ten isolates which were morphologically discrete were used for primary screening purpose. The bacterial isolate JRR34, showing significant inhibitory activity against bacterial pathogens $E$. coli, P. aeruginosa and $S$. aureus, was identified as Streptobacillus sp. using Bergey's manual. ${ }^{18}$ These pathogens selected cause human diseases like urinary tract infection, pneumonia and cellulitis and therefore the present study was focussed on the antibiosity of the crude extract of Streptobacillus sp. against these opportunistic pathogens. Rhizospheric bacteria often use the antibiotics produced as a competitive tool to survive in the soil environment. ${ }^{19}$ Bacteria with antimicrobial potential help improve plant health. ${ }^{20}$ and the bacterial interspecific interactions activates production of antibiotics. ${ }^{21,22}$ Optimization of media is important to maximize the production of secondary metabolites. Temperature and $\mathrm{pH}$ are significant factors affecting production of secondary metabolite. The selected isolate, Streptobacillus sp, grew profoundly in $\mathrm{pH} 5$ and at incubation temperature of $37^{\circ} \mathrm{C}$. In a similar study it was reported that Streptobacillus $\mathrm{sp}$. and Corynebacterium sp. showed optimum growth in $\mathrm{pH} 7$ and at a temperature of $32{ }^{\circ} \mathrm{C} .{ }^{23}$ Similarly, Streptomyces albidoflavus produced maximum antimicrobial compound at $\mathrm{pH} 7^{24,25}$ while optimum incubation temperature noted was $28^{\circ} \mathrm{C} .{ }^{26,27} \mathrm{~A}$ combination of lactose, yeast and $\mathrm{FeSO}_{4}, \mathrm{~K}_{2} \mathrm{HPO}_{4}$ showed optimum growth of Streptobacillus sp. in the present study. Kanmani et al. ${ }^{28}$ reported that production of bacteriocin which is responsible for antimicrobial property, in MRS media containing peptone, lactose and malt extract was maximum. Further it was observed
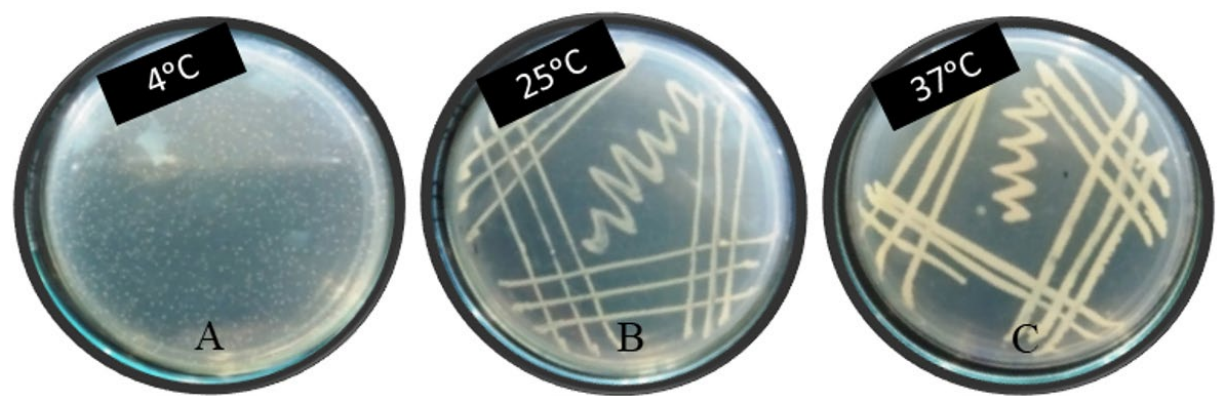

Fig. 4. Effect of temperature on growth of JRR34 (A) Streak plate at $4{ }^{\circ} \mathrm{C}$ (B) Streak plate at $25^{\circ} \mathrm{C}$ (C) Streak plate at $37^{\circ} \mathrm{C}$

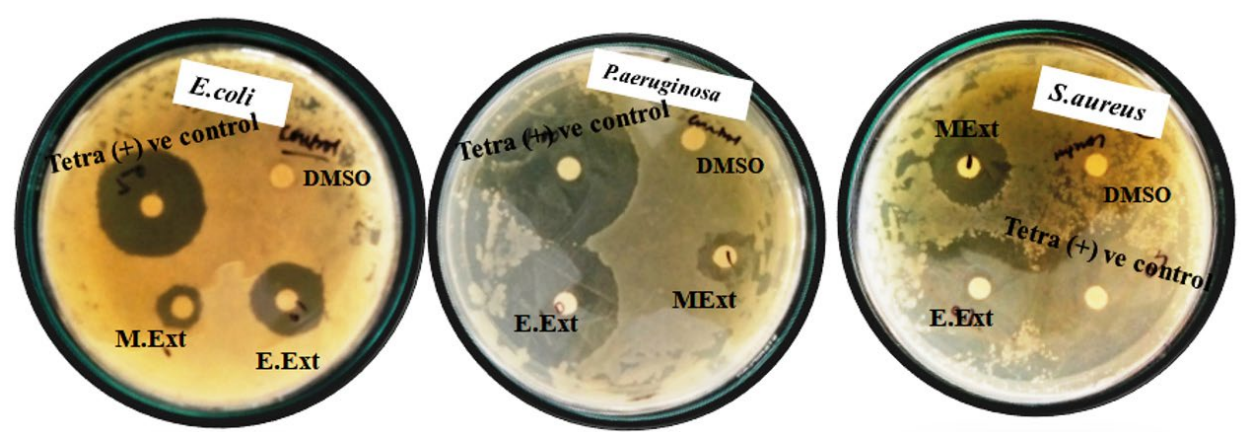

Fig. 5. Determination of antimicrobial activity of Streptobacillus sp. JRR34 crude extract obtained in different solvents against $E$. coli, P. aeruginosa and S. aureus by disc diffusion method. 


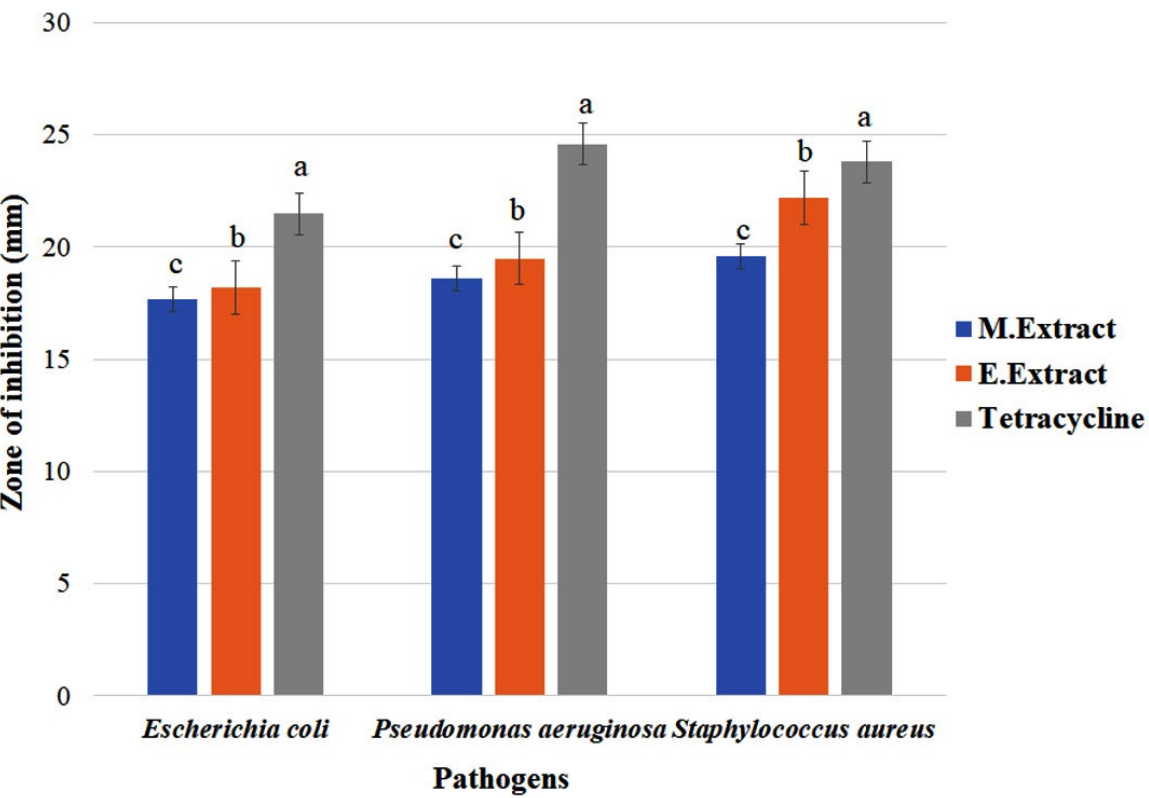

Fig. 6. Comparative analysis of zone of inhibition by Streptobacillus sp. crude extract obtained in different solvents against pathogens.

(Results are expressed as means of three replicates and vertical bars indicate standard deviations of the means. Different letters indicate significant differences among the results according to Duncan's multiple range test at $P \leq 0.05$ )

that $\mathrm{K}_{2} \mathrm{HPO}_{4}$ plays an important role in antibiotic production in Streptomyces fradiae. ${ }^{29}$ During the secondary screening process it was observed that methyl and ethyl extract of Streptobacillus sp. showed good antimicrobial property against $E$. coli, $P$. aeruginosa and $S$. aureus. The inhibitory effect was observed largely in ethyl extract. Similarly, Abeysinghe ${ }^{30}$ reported that ethanol extracts exhibited higher inhibition property than other aqueous solvents. Moreover, in the present study it was found that Streptobacillus sp. is susceptible to tetracycline which aligned with the results of Habib et al. ${ }^{23}$ which proved that Streptobacillus was resistant to trimethoprim-sulfamethoxazole and amoxicillin whereas it was susceptible to tetracycline and phenoxymethyl-penicilline, though it showed intermediate resistance towards Ciprofloxacin. Streptobacillus sp. exhibited more inhibitory action against $S$. aureus than $E$. coli and $P$. aeruginosa. However, it was observed that the susceptibility of gram negative bacteria was more as compared to gram positive bacteria, as the antimicrobial property was more noticeable against gram negative bacteria. This may indicate that the antibiotics produced cannot lyse the thick wall of peptidoglycan present in Gram positive bacteria. This study may contribute in understanding the biocontrol activity of Streptobacillus sp. and can be used in antibiotic therapy. As the present investigation is limited to few samples, it does not reveal the bigger picture but defined and precise result can be obtained if it is carried out widely.

\section{CONCLUSION}

The selected bacterial isolate JRR34 identified as Streptobacillus showed alterations in growth rate in response to modified growth media, $\mathrm{pH}$ and temperature. The inhibitory effects of Streptobacillus sp. ethyl crude extract against the pathogens E. coli, P. aeruginosa and S. aureus was significant as measured through antibiosis activity. The ethyl crude extract of Streptobacillus can be a vital source of novel antibiotics and the study also opens scope for extensive exploration against the multiple drug resistant microbes. 


\section{ACKNOWLEDGMENTS}

The authors would like to thank Principal, $\mathrm{MMV}, \mathrm{BHU}$ for providing all necessary facilities for carrying out the research work.

\section{CONFLICT OF INTEREST} conflict of interest.

The authors declare that there is no

\section{AUTHORS' CONTRIBUTION}

All authors listed have made a substantial, direct and intellectual contribution to the work, and approve it for publication.

\section{FUNDING}

This study was support as JRF and SRF (Grant No. 09/013(0810)-EMR-I), received from CSIR, Government of India, New Delhi, India.

\section{DATA AVAILABILITY}

All datasets obtained or studied during this study are incorporated in the manuscript.

\section{ETHICS STATEMENT}

This article does not contain any studies with human participants or animals performed by any of the authors.

\section{REFERENCES}

1. Ramos JL, Duque E, Gallegos MT, et al. Mechanism of solvent tolerance in gram-negative bacteria. Ann Rev Microbiol. 2002;56:743-768. doi: 10.1146/annurev. micro.56.012302.161038

2. Anwer H, Strap JL, Costerton JW. Establishment of ageing biofilms: possible mechanism of bacterial resistance to antimicrobial therapy. Antimicrob Agents Chemother. 1992;36(7):1347-1351. doi: 10.1128/ AAC.36.7.1347

3. Iwu CD, Korsten L, Okoh Al. The incidence of antibiotic resistance within and beyond the agricultural ecosystem: A concern for public health. MicrobiologyOpen. 2020;9(9):1035. doi: 10.1002/ mbo3.1035

4. Romero D, Traxler MF, Lopez D, Kolter R. Antibiotics as signal molecules. Chem Rev. 2011;111(9):5492-5505. doi: $10.1021 / \mathrm{cr} 2000509$

5. Gesheva V, Ivanova V, Gesheva R. Effects of nutrients on the production of AK-111-81 macrolide antibiotic by Streptomyces hygroscopicus. Microbiol Res. 2005;160(3):243-248. doi: 10.1016/j. micres.2004.06.005

6. Singh PK, Sharma V, Patil PB, Korpole S. Identification, purification and characterization of laterosporulin, a novel bacteriocin produced by Brevibacillus sp. strain GI-9. PLOS ONE. 2012;7(3):31498. doi: 10.1371/ journal.pone.0031498

7. Prasad JK, Pandey P, Anand R, Raghuwanshi R. Drought Exposed Burkholderia seminalis JRBHU6 Exhibits Antimicrobial Potential Through Pyrazine-1, 4-Dione Derivatives Targeting Multiple Bacterial and Fungal Proteins. Front Microbiol. 2021;12:633036. doi: 10.3389/fmicb.2021.633036

8. Aghamirian MR, Ghiasian SA. Isolation and characterization of medically important aerobic actinomycetes in soil of Iran (20062007). Open Microbiol. 2009;3:53-57. doi: 10.2174/1874285800903010053

9. Reddy N, Ramakrishna D, Gopal SVR. A morphological, physiological and biochemical studies of marine Streptomyces rochei (MTCC 10109) showing antagonistic activity against selective human pathogenic microorganisms. Asian J Biol Sci. 2011;4(1):1-14. doi: 10.3923/ajbs.2011.1.14

10. Shenpagam HN, Devi DK, Sinduja G, Sandhya R. Isolation of endophytic actinomycetes from medicinal plants and its mutational effect in biocontrol activity. In J Pharm Science Res. 2012;3(11):4338-4344. doi: 10.13040/IJPSR.0975-8232.3(11).4338-44

11. Sneath HAP, Halt GJ. Bergey's manual of systematic bacteriology Vol. 2 Baltimore, M.D.: Williams and Wilkins. 1986.

12. Egorov NS. Antibiotics: A scientific approach. Mir publishers, Moscow. 1985.

13. Romankova AG, Zurabova ER, Fursenko MV, Sukharevich $\mathrm{VI}$, Pronina MI. Selection of strains of some antibiotic producing Actinomycetes during repeated passages in submerged cultures. Antibiotiki. 1971;16(7):579-583.

14. Lakshmipatipathy D, Krishnan K. Antibacterial and antifungal activity of Streptomyces sp. VITDDK3 isolated from ennore coast, Tamil Nadu, India. Asian J Pharm Res Health Care. 2010;2(2):186-196.

15. Raja A, Prabakaran P. Preliminary screening of antimycobacterial effect of psychrophillic Actinomycetes isolated from Manali ice point: Himachal Pradesh. J Microbiol Antimicrobials. 2011;3(2):41-46.

16. Buchanan RF, Gibbons, NF. Bergey's Manual of Determinative Bacteriology. 9th edn. Baltimore, Williums and Wilkins Co. 1984.

17. Barrow GI, Feltham RKA. Cowan and Steel's Manual for the Identification of Medical Bacteria. 3rd edn. Cambridge University Press, Cambridge, New York. 1993.

18. Bergey DH, Breed RS, Murray EGD, Hitchens AP. Manual of determinative bacteriology. Fifth Edn. 1939.

19. Hibbing ME, Fuqua C, Parsek MR, Peterson SB. Bacterial competition: surviving and thriving in the microbial jungle. Nat Rev Microbiol. 2010;8:15-25. doi: 10.1038/ nrmicro2259

20. Raaijmakers JM, Mazzola M. Diversity and natural functions of antibiotics produced by beneficial and plant pathogenic bacteria. Annu Rev Phytopathol. 2012;50:403-424. doi: 10.1146/annurevphyto-081211-172908

21. Garbeva P, Silby MW, Raaijmakers JM, Levy SB, Boer W. Transcriptional and antagonistic responses of Pseudomonas fluorescens PfO-1 to phylogenetically 
different bacterial competitors. ISME J. 2011;5:973985. doi: 10.1038/ismej.2010.196

22. Seyedsayamdost MR, Traxler MF, Clardy J, Kolter R. Old meets new: using interspecies interactions to detect secondary metabolite production in actinomycetes. Methods Enzymol. 2012;517:89-109. doi: 10.1016/ B978-0-12-404634-4.00005-X

23. Habib SA, Fakhruddin ANM, Alam MK. Responses of laboratory stock culture contaminated bacteria against phenol, $\mathrm{pH}$, temperature and antibiotics. J Bangladesh Acad Science. 2010;34(2):133-141. doi: 10.3329/jbas. v34i2.6857

24. Narayana KJP, Vijayalakshmi M. Optimization of antimicrobial metabolites production by Streptomyces albidoflavus. Res J Pharmacol. 2008;2(1):4-7.

25. Sholkamy EN, Muthukrishnan P, Abdel-Raouf N, Nandhini X, Ibraheem IB, Mostafa AA. Antimicrobial and antinematicidal metabolites from Streptomyces cuspidosporus strain SA4 against selected pathogenic bacteria, fungi and nematode. Saudi J Biol Science. 2020;27(12):3208-3220. doi: 10.1016/j. sjbs.2020.08.043
26.

Mustafa O. Effect of some environmental condition on biomass and antimicrobial metabolite production by Streptomyces sp., KGG32. Int J Agri Biol. 2011;3(3):317324.

27. Yao X, Zhang Z, Huang J, et al. Candicidin Isomer Production Is Essential for Biocontrol of Cucumber Rhizoctonia Rot by Streptomyces albidoflavus W68. Appl Environ Microbiol. 2021;87(9):03078-20. doi: 10.1128/AEM.03078-20

28. Kanmani P, Yuvaraj N, Paari KA, Pattukumar V, Arul $V$. Optimization of media components for enhanced production of Streptococcus phocae PI80 and its bacteriocin using response surface methodology. Braz J Microbiol. 2011;42(2):716-720. doi: 10.1590/S151783822011000200038

29. Majumdar MK, Majumdar SK. Effect of minerals on neomycin production by Streptomyces fradiae. Appl Environ Microbiol. 1965;13(2):190-193. doi: 10.1128/ am.13.2.190-193.1965

30. Abeysinghe PD. Antibacterial activity of some medicinal mangroves against antibiotic resistant pathogenic bacteria. In J Pharm Science. 2010;72(2):167-172. doi: 10.4103/0250-474X.65019 